\title{
Study on the inflammatory intervention of erythropoietin on NEC
}

\author{
WEIBIN QI ${ }^{1}$, QIONG SHEN $^{2}$, LIN ZHANG $^{3}$, LI-PING HAN ${ }^{1}$ and SUMIN WANG ${ }^{1}$ \\ ${ }^{1}$ Department of Neonatology, The Fourth Hospital of Shijiazhuang, Shijiazhuang, Hebei 050011; \\ ${ }^{2}$ Department of Gynaecology and Obstetrics, Armed Police Hebei Corps Hospital, Shijiazhuang, Hebei 050081; \\ ${ }^{3}$ Department of Pediatrics, The Third Hospital of Hebei Medical University, Shijiazhuang, Hebei 050000, P.R. China
}

Received November 13, 2015; Accepted March 29, 2016

DOI: 10.3892/etm.2016.3199

\begin{abstract}
The aim of this study was to investigate the effect of erythropoietin (EPO) on the inflammatory response and the mechanism analysis of the Toll-like receptor 4 (TLR4)/nuclear factor- $\mathrm{\kappa B}$ (NF- $\mathrm{\kappa B}$ ) signaling pathway of NEC. A total of 94 patients with necrotizing enterocolitis (NEC) were randomly divided into the control (42 cases) and observation (52 cases) groups, The control group received the standard medical treatment plan, whereas for the observation group this treatment plan was combined with the application of recombinant EPO for intramuscular injection treatment. The clinical effect was subsequently compared. The results showed that the complication and death rates in the observation group were significantly lower than those in the control group with statistically significant differences $(\mathrm{P}<0.05)$. Following treatments, the levels of tumor necrosis factor- $\alpha$ (TNF- $\alpha$ ) and interleukin (IL)-6 in the observation group were significantly lower than those in the control group. The expression levels of mRNA of TLR4 and NF- $\mathrm{kB}$ in the observation group were significantly lower than those in the control group, with statistically significant differences $(\mathrm{P}<0.05)$. In summary, EPO was able to reduce the levels of inflammatory response of TNF- $\alpha$ and IL-6 through the TLR4/NF- $\mathrm{BB}$ signaling pathway, and improve the NEC, thus providing a basis for the clinical treatment of NEC.
\end{abstract}

\section{Introduction}

The main biological effect of erythropoietin (EPO) has been manifested through the promotion of proliferation,

Correspondence to: Dr Weibin Qi, Department of Neonatology, The Fourth Hospital of Shijiazhuang, 206 Zhongshan East Road, Shijiazhuang, Hebei 050011, P.R. China

E-mail: weibin_qi@163.com

Dr Lin Zhang, Department of Pediatrics, The Third Hospital of Hebei Medical University, 16 Weiming Street, Shijiazhuang, Hebei 050000, P.R. China

E-mail: linzhang_9@163.com

Key words: erythropoietin, necrotizing enteroolitis, inflammatory reaction, Toll-like receptor $4 /$ nuclear factor- $\kappa \mathrm{B}$ signaling pathway, tumor necrosis factor- $\alpha$, interleukin- 6 differentiation, and maturation of erythroid progenitor cells, as well as an increase in the number of red blood cells in the circulation (1). Therefore, EPO is widely used in the treatment of neonatal, cancer and renal anemia. Recent findings have shown that EPO and EPO receptors are widely distributed (2). They are expressed in a variety of non-hematopoietic tissues, and are also equipped with a variety of non-hematopoietic biological effects, such as angiogenic promotion, anti-inflammation, anti-apoptosis and neuroprotection and are considered to be a systemic protective cytokine (2). It has been found that breast milk contains EPO, and intestines of neonatals contain EPO receptors, which indicate that EPO may play an important physiological role in the growth and development of the gastrointestinal tract (3). Previous studies suggested that the recombinant EPO in a mouse model of neonatal necrotizing enterocolitis (NEC) can reduce the inflammatory reaction and improve NEC injury (4).

The aim of the present study was to examine the clinical effect of EPO on the inflammatory response and possible mechanism of action of the TLR4/NF- $\kappa B$ signaling pathway, through clinical trials, to provide a new basis for the clinical treatment of NEC.

\section{Patients and methods}

Patients. In total, 94 cases diagnosed with NEC between August, 2013 and August, 2015 were selected for the present study. The diagnosis of NEC conformed to the standard of the American Society for Parenteral and Enteral Nutrition (5). The study was approved by the Ethics Committee of The Fourth Hospital of Shijiazhuang. Informed consent from the guardian, according to the order of admission was obtained. The 94 patients with NEC were randomly divided into the control (42 cases) and observation (52 cases) groups. A comparison of the baseline information identified that differences were statistically significant $(\mathrm{P}<0.05)$. Table I shows that NEC staging was performed in accordance with the standard of Bell's NEC staging.

Research methods. The control group were given the standard medical treatment plan, which included fasting, no hydration, gastrointestinal decompression, parenteral nutrition, selection of sensitive antibiotics, early stage, full weight, appropriate amount of rehydration, maintainance of gastrointestinal tissue perfusion, correct anemia, electrolyte disorder, acid-base 
Table I. Comparison of baseline information between the control and observation groups.

\begin{tabular}{lrrrr}
\hline Group & $\begin{array}{c}\text { Control } \\
\text { group, } \mathrm{n}=42\end{array}$ & $\begin{array}{c}\text { Observation } \\
\text { group, } \mathrm{n}=52\end{array}$ & $\mathrm{t}\left(\chi^{2}\right.$ test $)$ & P-value \\
\hline Male/female & $23 / 19$ & $28 / 24$ & 0.008 & 0.929 \\
Age, day & $13.4 \pm 2.5$ & $12.5 \pm 2.4$ & 0.624 & 0.337 \\
Weight, kg & $2.2 \pm 0.6$ & $2.1 \pm 0.5$ & 0.421 & 0.564 \\
1 min Apgar & $8.2 \pm 0.7$ & $8.3 \pm 0.6$ & 0.519 & 0.768 \\
score & & & & \\
NEC staging & & & & \\
I & $6(14.3)$ & $6(11.5)$ & 0.920 & 0.631 \\
$\begin{array}{l}\text { II } \\
\text { III }\end{array}$ & $26(61.9)$ & $37(71.2)$ & & \\
$\begin{array}{l}\text { Premature } \\
\text { birth }\end{array}$ & $25(59.5)$ & $28(53.8)$ & 0.305 & 0.581 \\
$\begin{array}{l}\text { Caesarean } \\
\text { section }\end{array}$ & $20(47.6)$ & $23(44.2)$ & 0.107 & 0.743 \\
$\begin{array}{l}\text { Breast feeding } \\
\text { Milk powder }\end{array}$ & $29(69.0)$ & $33(63.5)$ & 0.373 & 0.830 \\
feeding & $6(14.3)$ & $8(15.4)$ & & \\
$\begin{array}{l}\text { Breast + milk } \\
\text { powder feeding }\end{array}$ & $7(16.7)$ & $11(21.2)$ & & \\
$\begin{array}{l}\text { Hemoglobin, } \\
\text { g/l }\end{array}$ & $185.6 \pm 13.7$ & $184.2 \pm 14.5$ & 0.967 & 0.325 \\
$\begin{array}{l}\text { Hematocrit } \\
\text { Hem }\end{array}$ & $62.4 \pm 1.7$ & $62.5 \pm 1.6$ & 0.624 & 0.857 \\
\hline
\end{tabular}

imbalance, blood pressure, heart rate, blood glucose and respiratory support. The abdominal X-ray was regularly performed to observe changes of the disease. If the disease was not relieved or continued to deteriorate with conservative treatment of internal medicine, surgical resection was subsequently performed. The observation group was treated with a combined application of recombinant EPO (National Medical License no. S20000007, 2,000 IU/dose; Shandong Kexing Bioproducts Co., Ltd., Shandong, China) for intramuscular injection, at a dose of $200 \mathrm{IU} / \mathrm{kg}$, twice a week for a total of 1 week. Any allergic reaction or other adverse reactions were observed closely.

Observation index and detection technology. The differences of the complication and death rates were compared between the two groups, including levels of tumor necrosis factor- $\alpha$ (TNF- $\alpha$ ), interleukin (IL)-6 and the mRNA expression levels of Toll-like receptor 4 (TLR4) and nuclear factor- $\kappa \mathrm{B}(\mathrm{NF}-\kappa \mathrm{B})$. Venous blood $(5 \mathrm{ml})$ was collected on an empty stomach and centrifuged at 2,800 $\mathrm{g}$ at high speed and the supernatant was removed after $5 \mathrm{~min}$. TNF- $\alpha$ and IL-6 kits were purchased from Shanghai J\&M Co. Ltd. (Shanghai, China). The ELISA method was applied and the experiment was performed according to the manufacturer's instructions. The expression of mRNA for TLR4 and NF- $\mathrm{kB}$ was detected by quantitative polymerase chain reaction (TaqMan probe method) and the SYBR-Green I staining method (Shinegene, Shanghai, China), respectively. Subsequently, the standard curves of the target genes (TLR4 and NF- $\kappa B$ ) and housekeeping genes (GAPDH) were created. By means of the standard curves, the expression of the target and housekeeping genes in the samples was quantified. The relative expression amount of TLR4 and $\mathrm{NF}-\kappa \mathrm{B}$ in each group was determined after correction of the housekeeping genes.

Statistical analysis. SPSS 20.0 statistical software (IBM SPSS, Armonk, NY, USA) was applied to determine statistical analysis. Measurement data were presented as mean \pm standard deviation. The t-test was applied for comparisons between groups and the Kruskal-Wallis $\mathrm{H}$ was applied to make pathological scoring of intestinal tissues. Enumeration data were presented as a percentage (\%). The $\chi^{2}$ test was applied for comparisons between groups. $\mathrm{P}<0.05$ was considered to indicate a statistically significant difference.

\section{Results}

Comparison of complication and death rates. The complication and death rates in the observation group were significantly lower than those in the control group and differences were statistically significant $(\mathrm{P}<0.05)$ (Tables I and II).

Comparison of the expression levels of TNF- $\alpha$ and $I L-6$. Prior to intervention, differences between the two groups with regard to the levels of TNF- $\alpha$ and IL- 6 were not statistically significant $(P>0.05)$. After intervention, the levels of TNF- $\alpha$ and IL- 6 of the control group were increased while the levels of the observation group were reduced. The levels of the observation group were significantly lower than those of the control group and differences were statistically significant $(\mathrm{P}<0.05)$ (Table III).

Comparison of mRNA expression levels of TLR4 and NF- $\kappa B$. Prior to intervention, differences between the two groups with regard to the mRNA expression levels of TLR4 and NF- $\mathrm{kB}$ were not statistically significant $(\mathrm{P}>0.05)$. After intervention, the mRNA expression levels of TLR4 and NF- $\kappa B$ in the two groups were significantly decreased and those in the observation were lower than those in the control group. Differences were statistically significant $(\mathrm{P}<0.05)$ (Table IV).

\section{Discussion}

EPO is a glycoprotein with a molecular weight of $30.4 \mathrm{kDa}$. In the fetus period, it is mainly synthesized by liver and post birth, and the kidney. Ledbetter and others (6) found from a retrospective study that the incidence of NEC on premature infants with EPO injection was significantly lower than that of infants not treated with EPO (7). To study the protective mechanism of EPO on NEC, Kumral and others (8) used EOP to preprocess hypoxia reperfusion NEC mice (EPO $750 \mathrm{U} / \mathrm{kg} /$ week, intraperitoneal injection in 3 shots for 2 weeks). On day 15, the animals were exposed to $100 \% \mathrm{CO}_{2}$ for anoxia for $5 \mathrm{~min}$, followed by reoxygenation with $100 \% \mathrm{O}_{2}$ for $10 \mathrm{~min}$, and then executed after $4 \mathrm{~h}$. Compared to the result of the experimental group, the level of nitric oxide in the EPO pretreatment group was significantly decreased, and the injury of the intestinal 
Table II. Comparison of complication and death rates.

\begin{tabular}{|c|c|c|c|c|c|c|c|}
\hline Group & Cases & Septicemia & $\begin{array}{c}\text { Acute intestinal } \\
\text { perforation }\end{array}$ & $\begin{array}{l}\text { Infectious } \\
\text { peritonitis }\end{array}$ & Others & $\begin{array}{l}\text { Complication } \\
\text { rate }\end{array}$ & $\begin{array}{l}\text { Death } \\
\text { rate }\end{array}$ \\
\hline Control group & 42 & 7 & 6 & 6 & 2 & $21(50.0)$ & $11(26.2)$ \\
\hline Observation group & 52 & 5 & 5 & 4 & 2 & $16(30.8)$ & $5(9.6)$ \\
\hline$\chi^{2}$ test & & & & & & 3.868 & 4.519 \\
\hline P-value & & & & & & 0.049 & 0.034 \\
\hline
\end{tabular}

Table III. Comparison of the levels of TNF- $\alpha$ and IL- 6 between the observation and control groups.

\begin{tabular}{|c|c|c|c|c|}
\hline \multirow[b]{2}{*}{ Group } & \multicolumn{2}{|c|}{ TNF- $\alpha, n g / 1$} & \multicolumn{2}{|c|}{ IL-6, ng/l } \\
\hline & Pre-intervention & Post-intervention & Pre-intervention & Post-intervention \\
\hline Control & $56.7 \pm 6.4$ & $78.4 \pm 10.2$ & $241.3 \pm 36.9$ & $287.5 \pm 48.7$ \\
\hline Observation & $61.2 \pm 6.8$ & $32.5 \pm 4.8$ & $259.6 \pm 42.3$ & $143.2 \pm 32.5$ \\
\hline t-test & 0.529 & 6.498 & 0.629 & 6.213 \\
\hline P-value & 0.423 & 0.012 & 0.415 & 0.018 \\
\hline
\end{tabular}

TNF- $\alpha$, tumor necrosis factor- $\alpha$; IL- 6 , interleukin-6.

Table IV. Comparison of mRNA expression levels of TLR4 and NF- $\kappa$ B.

\begin{tabular}{|c|c|c|c|c|}
\hline \multirow[b]{2}{*}{ Group } & \multicolumn{2}{|c|}{ TLR4 } & \multicolumn{2}{|c|}{$\mathrm{NF}-\kappa \mathrm{B}$} \\
\hline & Pre-intervention & Post-intervention & Pre-intervention & Post-intervention \\
\hline Control & $3.3 \pm 0.5$ & $2.6 \pm 0.3$ & $2.4 \pm 0.6$ & $1.8 \pm 0.2$ \\
\hline Observation & $3.6 \pm 0.7$ & $1.2 \pm 0.4$ & $2.7 \pm 0.5$ & $0.7 \pm 0.1$ \\
\hline t-test & 0.924 & 7.436 & 0.825 & 8.125 \\
\hline P-value & 0.721 & $<0.001$ & 0.364 & $<0.001$ \\
\hline
\end{tabular}

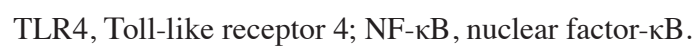

tissue was reduced, indicating that EPO retarted the occurrence of NEC in mice by inhibiting the excessive production of nitric oxide (9). Akisu and others (10) used the same method to study the role of EPO in the production of intestinal malondialdehyde (MDA) and platelet activating factor (PAF). Their study results showed that although EPO cannot inhibit the production of PAF in the necrotic intestine tissues resulting from hypoxia reperfusion, it can significantly decrease the MDA content in the intestinal tissues of mice, indicating that EPO may play a role in the prevention and treatment of NEC by inhibiting the lipid peroxidation mediated by oxygen-free radicals (11). Shiou and others (12) have shown that supplementing EPO via the intestinal tract upregulated the expression of ZO-1, a tight junction protein in the enterocytes of NEC mice, which protected the intestinal mucosal barrier function (13). Halpern and Denning (7) used 3-day SD mice and constructed a NEC model after artificial feeding and hypoxia cold stimulation, and intervened by supplementing EPO of a similar physiological concentration as breast milk through the intestinal tract. Their study results showed that EPO downregulated the expression of TLR4 in intestinal tissues of mice and inhibited the inflammatory cascade reaction, reduced the intestinal tissue damage, retarted the malignant progression, and finally reduced the occurrence of bacterial translocation $(3,12)$.

The role of TLR4 in the pathogenesis of NEC has aroused increasing attention (14). The expression of TLR4 in normal intestinal epithelial cells is low, whereas that in NEC children and animal models is high. The high expression of TLR4 appeared even before NEC tissue injury. High-risk factors of NEC, including premature birth, artificial feeding, hypoxia ischemia, and bacterial factors can lead to an increase of TLR4 expression (4). The role of TLR4 in the pathogenesis of NEC was mainly associated with inflammation and repair (15). Activated TLR4 can activate $\mathrm{NF}-\kappa \mathrm{B}$, and induce the upregulated expression of downstream inflammatory cytokines. $\mathrm{NF}-\kappa \mathrm{B}$ in intestinal tissues removed from animal models and NEC children showed a sustained high expression, while the expression of the inflammatory cytokines in the lower reaches, such as TNF- $\alpha$, IL-6 and IL-8, also increased. A large number of inflammatory mediators leads to damage in the intestinal 
epithelial cells and mucosal defense mechanism, which would ultimately develop into NEC. Inhibiting of the TLR4 pathway can significantly reduce the expression of inflammatory mediators, alleviate macrophage infiltration, and reduce the occurrence of bacterial translocation $(16,17)$.

Results of the present study show that the complication and death rates in the observation group were lower than those in the control group. The levels of TNF- $\alpha$ and IL-6 in the observation group were significantly lower than those in the control group. The mRNA expression levels of TLR4 and $\mathrm{NF}-\kappa \mathrm{B}$ in the observation group were significantly lower than those in the control group, and differences were statistically significant. In conclusion, EPO can reduce the levels of inflammatory response of TNF- $\alpha$ and IL-6 through the TLR4/NF- $\kappa$ B signaling pathway and improve NEC, thereby providing a basis for the clinical treatment of NEC.

\section{References}

1. Cody JD and Hodson EM: Recombinant human erythropoietin versus placebo or no treatment for the anaemia of chronic kidney disease in people not requiring dialysis. Cochrane Database Syst Rev 1: CD003266, 2016.

2. Lopez E, Beuchée A, Truffert P, Pouvreau N, Patkai J, Baud O, Boubred F, Flamant C and Jarreau PH: Recombinant human erythropoietin in neonates: Guidelines for clinical practice from the French Society of Neonatology. Arch Pediatr 22: 1092-1097, 2015 (In French).

3. Yu Y, Shiou SR, Guo Y, Lu L, Westerhoff M, Sun J, Petrof EO and Claud EC: Erythropoietin protects epithelial cells from excessive autophagy and apoptosis in experimental neonatal necrotizing enterocolitis. PLoS One 8: e69620, 2013.

4. Nanthakumar N, Meng D, Goldstein AM, et al: The mechanism of excessive intestinal inflammation in necrotizing enterocolitis: An immature innate immune response. PLoS One 6: e17776, 2011.

5. Fallon EM, Nehra D, Potemkin AK, Gura KM, Simpser E and Compher C: A.S.P.E.N. clinical guidelines: Nutrition support of neonatal patients at risk for necrotizing enterocolitis. J Parenter Enteral Nutr 36: 506-523, 2012.
6. Ledbetter DJ, Joyce AE, Dame C, Christensen RD, Zhao Y, DeMarco V and Juul SE: Erythropoietin acts as a trophic factor in neonatal rat intestine. Gut 49: 182-189, 2001.

7. Halpern MD and Denning PW: The role of intestinal epithelial barrier function in the development of NEC. Tissue Barriers 3: e1000707, 2015.

8. Kumral A, Baskin H, Duman N, Yilmaz O, Tatli M, Ozer E, Gökmen N, Genc S and Ozkan H: Erythropoietin protects against necrotizing enterocolitis of newborn rats by the inhibiting nitric oxide formation. Biol Neonate 84: 325-329, 2003.

9. Fauchère JC, Koller BM, Tschopp A, Dame C, Ruegger C and Bucher HU; Swiss Erythropoietin Neuroprotection Trial Group: Safety of early high-dose recombinant erythropoietin for neuroprotection in very preterm infants. J Pediatr 167: 52-7.e1-3, 2015.

10. Akisu M, Baka M, Huseyinov A and Kultursay N: The role of dietary supplementation with L-glutamine in inflammatory mediator release and intestinal injury in hypoxia/reoxygenationinduced experimental necrotizing enterocolitis. Ann Nutr Metab 47: 262-266, 2003.

11. Seikku L, Rahkonen L, Tikkanen M, Hämäläinen E, Rahkonen P, Andersson S, Teramo K, Paavonen J and Stefanovic V: Amniotic fluid erythropoietin and neonatal outcome in pregnancies complicated by intrauterine growth restriction before 34 gestational weeks. Acta Obstet Gynecol Scand 94: 288-294, 2015.

12. Shiou SR, Yu Y, Chen S, Ciancio MJ, Petrof EO, Sun J and Claud EC: Erythropoietin protects intestinal epithelial barrier function and lowers the incidence of experimental neonatal necrotizing enterocolitis. J Biol Chem 286: 12123-12132, 2011.

13. Wang H, Zhang L and Jin Y: A meta-analysis of the protectiveeffect of recombinant human erythropoietin (rhEPO) for neuro-development in preterm infants. Cell Biochem Biophys 71: 795-802, 2015.

14. Yamamoto $\mathrm{M}$ and Takeda $\mathrm{K}$ : Current views of toll-like receptor signaling pathways. Gastroenterol Res Pract 2010: 240365, 2010.

15. Chan KL, Wong KF and Luk JM: Role of LPS/CD14/TLR4mediated inflammation in necrotizing enterocolitis: Pathogenesis and therapeutic implications. World J Gastroenterol 15: 4745-4752, 2009.

16. Rhee SH: Basic and translational understandings of microbial recognition by toll-like receptors in the intestine. J Neurogastroenterol Motil 17: 28-34, 2011.

17. Sodhi CP, Shi XH, Richardson WM, Grant ZS, Shapiro RA, Prindle T Jr, Branca M, Russo A, Gribar SC, Ma C, et al: Toll-like receptor-4 inhibits enterocyte proliferation via impaired $\beta$-catenin signaling in necrotizing enterocolitis. Gastroenterology 138: 185-196, 2010. 